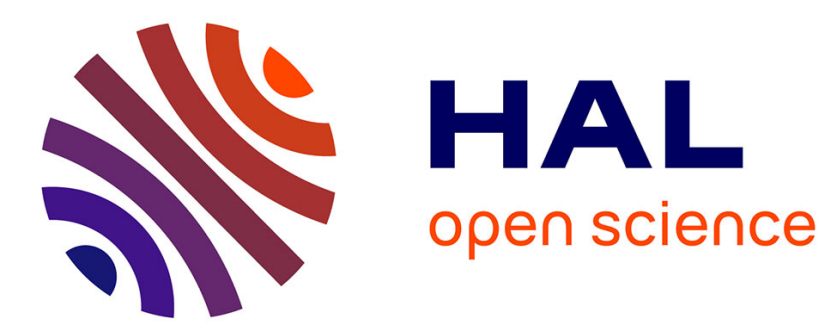

\title{
Taxing aid: the end of a paradox?
}

Emilie Caldeira, Anne-Marie Geourjon, Grégoire Rota-Graziosi

\section{To cite this version:}

Emilie Caldeira, Anne-Marie Geourjon, Grégoire Rota-Graziosi. Taxing aid: the end of a paradox? International Tax and Public Finance, 2019, 27, pp.240-255. 10.1007/s10797-019-09573-6 . hal02320206

\section{HAL Id: hal-02320206 https://hal.science/hal-02320206}

Submitted on 26 Oct 2021

HAL is a multi-disciplinary open access archive for the deposit and dissemination of scientific research documents, whether they are published or not. The documents may come from teaching and research institutions in France or abroad, or from public or private research centers.
L'archive ouverte pluridisciplinaire HAL, est destinée au dépôt et à la diffusion de documents scientifiques de niveau recherche, publiés ou non, émanant des établissements d'enseignement et de recherche français ou étrangers, des laboratoires publics ou privés. 


\title{
Taxing Aid: The end of a paradox?
}

Émilie Caldeira, ${ }^{(*)}$ Anne-Marie Geourjon, ${ }^{(\#)}$ and Grégoire Rota-Graziosi. ${ }^{(*, \#)}$

\begin{abstract}
:
Taxing aid was often discussed, but never implemented. This issue has now returned to the fore. First, many developing countries reform their tax system becoming more "reasonable" and eliminating one of the main justifications for aid-related tax exemptions. Second, the International Conference on Financing for Development held in Addis Ababa in August 2015 emphasised domestic revenue mobilisation as the main source of development finance. However, the broadening of tax base faces the proliferation of special tax arrangements, fuelled in part by the tax-exempt status of Official Development Assistance (ODA). Exemptions for project aid could represent as much as 3 percent of gross domestic product (GDP) in countries where tax revenues barely surpass 15 percent of GDP. In addition to loss of tax revenue, tax exemptions for project aid have particularly damaging effects on the formalisation of the economies of recipient countries. Moreover, systematic exemption reduces the credibility of the policies of donor countries and the consistency of their aid policy. Last, the taxation of aid meets the commitment made by donors in the Paris Declaration on Aid Effectiveness (2005) to use recipient countries' national Public Finance Management (PFM) systems. This note reviews tax exemptions of foreign aid-funded projects: their consequences in terms of domestic revenue mobilization in recipient countries, the induced inconsistency of foreign aid policy, their main historical justifications, and recent moves from some donor countries towards the taxation of their aid.
\end{abstract}

$\left(^{*}\right)$ Université Clermont Auvergne, CNRS, IRD, CERDI, F-63000 Clermont-Ferrand, France.

(\#) Fondation pour les Etudes et Recherches sur le Développement International, FERDI, France. 
The conference on development finance held in 2015 in Addis Ababa emphasized domestic resource mobilization as the largest source of development finance. ${ }^{1}$ While ODA efforts have stagnated in most Development Assistance Committee (DAC) countries, ${ }^{2}$ domestic resource mobilisation remains insufficient (Keen et al., 2010). The tax reforms undertaken in developing countries since the 1980s have paved the way for a first-generation tax transition, consisting in offsetting the fall in external revenues from international trade under the effect of the dismantling of tariff barriers. However, volume targets for domestic resource mobilisation have not been met (Op de Beke, 2014). Despite an upward trend, Sub-Saharan African countries mobilised on average barely 15 percent of their GDP in tax revenue (excluding natural resources) in 2014. The corresponding figure for OECD member states was 33 percent. $^{3}$ Developing countries have continued to make efforts to improve their tax systems via tax legislation and capacity building among tax and customs administrations or authorities. These reforms have generally sought to broaden the tax base, lower tax rates, and restructure and modernise tax and customs administrations. However, special tax arrangements - tax exemptions, reduced rates, tax relief - have proliferated in developing countries, where tax exemptions have often seemed a necessary condition to attract foreign direct investment in light of infrastructure deficiencies and skilled labour shortages. ${ }^{4}$ Like the informal sector, these special tax arrangements help to explain why developing countries are characterised by high tax rates, narrow bases, and low tax revenue to GDP ratios.

Some developing countries have therefore made significant efforts to better identify and control these tax exemptions, which are sometimes granted outside of any legal framework (IMF, 2011). ${ }^{5}$ Tax expenditures assessments and their publication in the appendices of finance laws have contributed to their rationalisation and have improved governments' fiscal transparency. The elimination of some tax exemptions clearly helps improve domestic resource mobilisation. Against this backdrop, tax expenditures related to project aid are paradoxical since they directly hamper developing countries' capacity to mobilise tax revenue. ${ }^{6}$ For instance, a massive inflow

\footnotetext{
1 This tax revenue does not include external tax revenue in the form of tariff receipts or any levies raised on countries' foreign trade, which have declined.

2 In 2014, ODA represented only $23 \%$ of finance provided by developed countries (OECD data).

${ }^{3}$ Authors' calculation based on UNU-Wider database (https://www.wider.unu.edu/project/government-revenue-dataset).

${ }^{4}$ For example, Mansour and Rota-Graziosi (2014) show that WAEMU member states compete mainly via special tax arrangements offered to firms as most member states' taxes and duties are regulated by widely-followed community directives.

${ }^{5}$ Notable sources of tax expenditure are sectoral codes (mining, oil), investment codes, ministerial decrees, and even establishment agreements and ad hoc decisions.

${ }^{6}$ Broadly speaking, there are two types of aid: Project aid, which consists in financing certain public goods or services, in particular infrastructure (roads, bridges, ports), and budget support, which consists of transfers to the government of a developing country. Project aid represents around 70\% of all ODA (see Chart 1 ).
} 
of aid in the form of foreign-funded projects in a failed state will help improve its growth and therefore GDP but will have no positive effect on the country's tax revenue. Its tax revenue to GDP ratio will even decrease.

The vast literature on aid effectiveness (see Clemens et al., 2012 for a review) does not address the issue of aid tax exemptions. ${ }^{7}$ However, Burnside and Dollar (2000) introduced the role of institutional quality as a condition for aid effectiveness. This paper triggered an academic debate and influenced multilateral development banks and some donor governments to review their aid allocation policy in favor of countries with stronger policies and institutions. Moreover, several studies have shown a negative effect of ODA on domestic resource mobilisation, in particular in low-income countries with weak institutions (Benedek et al., 2012). ${ }^{8}$ These studies have also underlined the importance of the composition of aid. Gupta et al. (2004) concluded that general budget support has a disincentive effect on domestic resource mobilisation. In the long term, aid reduces the accountability of governments in developing countries and affects governance in these countries (see Djankov et al. 2008). ${ }^{9}$

In addition to the accounting effect, tax exemptions for public aid from institutions such as NonGovernmental Organizations (NGOs) may sustain informality in recipient countries and therefore their inability to mobilise more tax revenue. ${ }^{10}$ Indeed, tax exemptions are particularly harmful regarding value added tax (VAT) as they break the payment-deduction chain of this tax and favour imports at the expense of locally supplied goods and services. A local supplier for a tax-exempt project can entirely bypass the tax authorities since their client (donor or NGO) does not carry over deductible VAT when purchasing of goods and services. Last, the proliferation of special tax arrangements significantly complicates the work of tax and customs administrations (or authorities) and significantly increases the risk of fraud and corruption. ${ }^{11}$ The paper is structured as follows: Section 2 reviews the distortion costs of project aid tax exemption; Section 3 presents the policy initiative to remove project aid tax exemptions; Section 4 concludes.

\footnotetext{
${ }^{7}$ A recent exception is Steel et al. (2018), who discuss the rationale for ODA tax exemptions through a survey covering 47 countries.

${ }^{8}$ Such a crowding out effect of aid is not new in the literature. Focusing on the United States Public Law 480, which established the American food aid program in 1954, Schultz (1960) stressed the risk of a disincentive effect of this aid on domestic agricultural producers in recipient countries.

${ }^{9}$ Nevertheless, this work has recently been the subject of debate, and new studies have showed that the negative relationship put forward is not so robust. In particular, Clist and Morrissey (2011) and Carter (2013) showed that this relationship is not robust relative to sample or specification changes and that it results from an endogeneity bias. Responding to the work of Benedek et al. (2012), Clist (2014) also concluded that these studies were not robust and attributed the negative effect of aid to poor econometric specifications and failure to take into account the obvious presence of endogeneity bias.

${ }^{10}$ These exemptions even create the need for further aid, leading to the Samaritan dilemma described by Buchanan (1975).

${ }^{11}$ For example, with the complicity of a customs officer, a merchant could claim a tax exemption granted to a donor and import goods free of any tax or duty without the donor knowing.
} 


\section{The distortion costs of project aid tax exemption}

Project aid tax exemptions trigger several distortion costs in recipient countries. In particular, these donors' policies contribute to reduce tax revenue, fuel a culture of exemptions, favour imports at the expense of locally provided goods and services.

First, the proliferation of tax exemptions may erode significantly tax bases and deteriorates domestic resource mobilisation in developing countries. The non-taxation of aid is one component of this problem and can hardly be addressed in isolation. Another source of tax exemptions and even tax frauds is the poor implementation of the Vienna Convention on diplomatic relations of 1961, which specifies the privileges of diplomatic missions. Tax and tariffs exemptions are generally extended to service staff of diplomatic or consular missions in developing countries, even though this staff is not directly concerned by the Vienna Convention. ${ }^{12}$ This generous interpretation of the Convention may be viewed as an additional tax expenditure. However, as ODA accounts for a sizeable share of GDP in most developing countries - especially in weak states - exempting it from tax leads to a more significant loss of tax revenue for these countries. Although low-income countries' reliance on ODA has tended to decline over the past 20 years, in 2015 ODA still represented on average 8.7 percent of gross national income (GNI). This figure was as high as 30 percent of GNI in the Central African Republic, 21 percent in Afghanistan, and 12 percent in Burundi and Gambia. ${ }^{13}$ Further, project aid has increased in recent years, rising from 61 to 82 billion dollars between 2007 and 2015 at an annual average growth rate of 3.7 percent (see Figure 1).

Table 1 displays a simple computation of tax revenues losses resulting from aid exemptions for $2016 .{ }^{14}$ We notice that the tax exemption of foreign aid is important in more than 20 countries, in which revenue losses exceed one percentage point of GDP. In Malawi, Mozambique, and Rwanda this figure is around 3 percent of GDP or above. ${ }^{15}$ If we consider only indirect taxes (tariffs included), ${ }^{16}$ revenue losses remain large in ten countries. This second estimation

\footnotetext{
12 The reciprocity principle may allow an extension of some tax advantages. However, this principle does not seem relevant when it is applied between developed and developing countries. Moreover, numerous scandals of tax abuse prejudice current practices.

13 Authors' calculation based on World Bank data.

${ }^{14}$ We compile the datasets on tax revenues provided from the UNU-Wider (https://www.wider.unu.edu/project/governmentrevenue-dataset) and on aid from the OECD (https://data.oecd.org/oda/net-oda.htm). We multiply the total tax and indirect taxes revenue to GDP ratios by the aid to GDP ratio. We deduce then an estimate of total tax and indirect taxes revenue losses resulting from the tax exemption of aid.

${ }^{15}$ For Liberia, this figure rises even to 7.43 percent but we should be cautious with the accuracy of used data since the UNU-Wider tax revenue to GDP ratio is equal to 31.04 percent, this same ratio is equal 12.9 percent in 2013 in the Government Finance Statistics of the International Monetary Fund.

16 Steel et al (2018) stressed that VAT and duties exemptions are far more frequent than other tax exemptions.
} 
provides a lower limit of revenue losses. These estimations remain obviously very preliminary, but highlight the potential impact of tax exemption of aid.

For MAEE (2010), tax exemptions for project aid may represent a tax revenue shortfall around 2 percent to 3 percent of GDP depending on the country. In 2009, the OECD's Task Team on Taxation and Accountability and ATAF (OECD, 2009) estimated that revenue losses represented 18 percent of funded projects and 10 percent of overall tax revenue in Niger. In Tanzania, exemptions on customs duties for donors amounted to 17 percent of the gross value of imports. The tax administration in Madagascar includes the taxation of aid in the benchmark tax system and provides estimates of the cost of these exemptions (Ministry of Finance and the Budget, 2017). Among the identified 243 tax expenditures, 34 percent of these concerns foreign aid, ahead of the mining (11 percent) and healthcare (5 percent) sectors. ${ }^{17}$ In Burkina Faso, exemptions for donor-financed projects (excluding NGOs) resulted in a loss of revenue of CFAF 13 billion in 2016. Between January and October 2017, the loss of revenue reached CFAF 19 billion, or 20 percent of total customs revenue losses (all taxes and duties combined) related to exempt imports (all categories) and 4 percent of the total amount of taxes and duties paid over the same period for imports. ${ }^{18}$

Beyond the resulting direct loss of revenue, non-taxation of project aid encourages the development of a governance culture of exemptions. It incentivises claims for exemptions, resulting in the multiplication of legal texts, a lack of transparency over tax law, and reduced the effectiveness of tax audits. It also runs counter to the main objective of the tax system reforms encouraged by donors, namely the widespread application of ordinary tax law. In particular, emerging countries - especially China - seek to benefit from the same treatment, while it can be difficult in practice to distinguish between what is and is not ODA. NGOs, which are often involved in implementing externally funded projects, enjoy the same exemptions. Given their number and diversity, the risk of fraud is considerable. ${ }^{19}$

\footnotetext{
${ }^{17}$ As in many developing countries, it is impossible to estimate the cost of customs exemptions granted in Madagascar to project aid from customs data: 1) the codes used for exemptions in the computer system do not separate them; and 2) they are sometimes considered fully taxed imports if taxes and duties are collected as "balancing transactions."

${ }^{18}$ Authors' calculation.

${ }^{19}$ For example, apart from frequent and practically uncontrollable misappropriations, exemptions create opportunities for customs evasion through the fraudulent use of the tax identification number of the development partner without its knowledge.
} 
Table 1: Tax revenue losses from the exemption of foreign aid in $\mathbf{2 0 1 6}$

\begin{tabular}{|c|c|c|c|c|c|c|c|}
\hline Country & $\begin{array}{l}\text { Total tax } \\
\text { revenue } \\
\text { losses (\% } \\
\text { GDP) }\end{array}$ & $\begin{array}{c}\text { Indirect tax } \\
\text { revenue } \\
\text { losses ( } \% \\
\text { GDP) } \\
\end{array}$ & $\begin{array}{l}\text { Aid (USD, } \\
\text { const, } \\
\text { Millions) }\end{array}$ & $\begin{array}{c}\text { GDP (USD, } \\
\text { const, } \\
\text { Millions) }\end{array}$ & $\begin{array}{c}\text { Aid } \\
\text { (\%GDP) }\end{array}$ & $\begin{array}{c}\text { Tax } \\
\text { revenue } \\
\text { to GDP }\end{array}$ & $\begin{array}{c}\text { Indirect } \\
\text { tax } \\
\text { revenue to } \\
\text { GDP }\end{array}$ \\
\hline Algeria & 0,03 & 0,01 & 189 & 199000 & 0,09 & 28,97 & 7,58 \\
\hline Armenia & 0,44 & 0,23 & 256 & 12365 & 2,07 & 21,11 & 11,00 \\
\hline Bangladesh & 0,20 & 0,12 & 3760 & 180000 & 2,09 & 9,71 & 5,79 \\
\hline Belize & 0,61 & & 34 & 1602 & 2,13 & 28,73 & \\
\hline Benin & 1,06 & & 676 & 9634 & 7,01 & 15,17 & \\
\hline Bolivia & 1,13 & 0,58 & 949 & 27881 & 3,40 & 33,22 & 16,99 \\
\hline Brazil & 0,00 & 0,00 & 272 & 2280000 & 0,01 & 30,92 & 13,83 \\
\hline Burkina Faso & 1,61 & & 890 & 13162 & 6,76 & 23,81 & \\
\hline Cambodia & 0,93 & 0,54 & 856 & 18216 & 4,70 & 19,73 & 11,56 \\
\hline Cameroon & 0,55 & 0,30 & 1210 & 36365 & 3,33 & 16,49 & 9,08 \\
\hline Chad & 0,64 & & 648 & 12265 & 5,28 & 12,07 & \\
\hline Costa Rica & 0,03 & 0,02 & 98 & 48174 & 0,20 & 14,13 & 8,77 \\
\hline Dominica & 1,26 & 0,70 & 19 & 457 & 4,15 & 30,27 & 16,80 \\
\hline Dominican Republic & 0,02 & 0,01 & 118 & 77017 & 0,15 & 14,75 & 8,92 \\
\hline El Salvador & 0,11 & 0,06 & 151 & 21988 & 0,69 & 16,37 & 9,43 \\
\hline Equatorial Guinea & 0,01 & & 7 & 14300 & 0,05 & 18,70 & \\
\hline Ethiopia & 1,13 & 0,55 & 4120 & 58320 & 7,07 & 16,02 & 7,77 \\
\hline Gabon & 0,10 & 0,04 & 106 & 19005 & 0,56 & 17,13 & 7,21 \\
\hline Georgia & 0,80 & 0,41 & 446 & 15923 & 2,80 & 28,52 & 14,60 \\
\hline Ghana & 0,43 & 0,25 & 1260 & 50620 & 2,50 & 17,08 & 10,05 \\
\hline Grenada & 0,15 & 0,09 & 6 & 979 & 0,58 & 26,35 & 15,75 \\
\hline Guatemala & 0,07 & 0,04 & 366 & 52841 & 0,69 & 10,62 & 6,44 \\
\hline Guinea & 0,69 & 0,41 & 457 & 10778 & 4,24 & 16,23 & 9,70 \\
\hline Guinea-Bissau & 1,65 & & 113 & 1123 & 10,08 & 16,40 & \\
\hline Guyana & 0,45 & 0,22 & 51 & 2987 & 1,71 & 26,08 & 12,84 \\
\hline Honduras & 0,64 & 0,29 & 441 & 20368 & 2,17 & 29,41 & 13,39 \\
\hline Indonesia & 0,00 & & 262 & 1090000 & 0,02 & 12,54 & \\
\hline Jordan & 2,37 & 1,08 & 2920 & 31614 & 9,24 & 25,70 & 11,64 \\
\hline Kenya & 0,75 & & 2480 & 58109 & 4,26 & 17,64 & \\
\hline Lebanon & 0,56 & 0,25 & 1310 & 42719 & 3,06 & 18,39 & 8,14 \\
\hline Lesotho & 2,13 & 1,13 & 147 & 2912 & 5,04 & 42,18 & 22,33 \\
\hline Liberia & 7,49 & & 622 & 2577 & 24,14 & 31,03 & \\
\hline Madagascar & 1,07 & 0,58 & 771 & 10802 & 7,13 & 14,99 & 8,17 \\
\hline Malawi & 3,27 & 1,33 & 1520 & 9059 & 16,72 & 19,53 & 7,95 \\
\hline Maldives & 0,31 & 0,17 & 43 & 3914 & 1,10 & 28,38 & 15,33 \\
\hline Mali & 1,76 & 1,00 & 1360 & 14147 & 9,59 & 18,29 & 10,47 \\
\hline Mauritania & 1,38 & & 284 & 5735 & 4,96 & 27,91 & \\
\hline Mauritius & 0,02 & & 12 & 12898 & 0,09 & 20,12 & \\
\hline Mongolia & 1,18 & 0,72 & 764 & 12443 & 6,14 & 19,26 & 11,71 \\
\hline Morocco & 0,41 & 0,21 & 1890 & 119000 & 1,58 & 26,02 & 13,17 \\
\hline Mozambique & 3,04 & 1,25 & 1790 & 15401 & 11,63 & 26,13 & 10,77 \\
\hline Myanmar & 0,36 & & 1540 & 79496 & 1,94 & 18,49 & \\
\hline Namibia & 0,40 & 0,22 & 187 & 14880 & 1,25 & 31,58 & 17,35 \\
\hline Nepal & 1,38 & 0,80 & 1270 & 21464 & 5,91 & 23,32 & 13,51 \\
\hline Paraguay & 0,06 & 0,04 & 142 & 36207 & 0,39 & 16,48 & 9,68 \\
\hline Philippines & 0,01 & 0,00 & 157 & 303000 & 0,05 & 15,16 & 7,31 \\
\hline Rwanda & 2,97 & 1,17 & 1230 & 9354 & 13,10 & 22,69 & 8,95 \\
\hline Senegal & 1,06 & 0,56 & 910 & 22965 & 3,96 & 26,77 & 14,09 \\
\hline Seychelles & 0,52 & 0,28 & 19 & 1343 & 1,38 & 37,63 & 20,04 \\
\hline South Africa & 0,09 & 0,03 & 1010 & 427000 & 0,24 & 36,64 & 11,75 \\
\hline Sri Lanka & 0,05 & 0,04 & 297 & 82651 & 0,36 & 14,15 & 10,18 \\
\hline Sudan & 0,11 & 0,06 & 840 & 79411 & 1,06 & 10,01 & 5,47 \\
\hline Tajikistan & 1,00 & & 317 & 9101 & 3,48 & 28,80 & \\
\hline Tanzania & 0,70 & 0,38 & 2580 & 49737 & 5,19 & 13,49 & 7,25 \\
\hline Thailand & 0,01 & 0,01 & 250 & 424000 & 0,06 & 20,78 & 10,67 \\
\hline Togo & 1,80 & 1,26 & 345 & 5058 & 6,81 & 26,45 & 18,56 \\
\hline Tunisia & 0,36 & 0,19 & 775 & 49666 & 1,56 & 22,81 & 12,31 \\
\hline Uganda & 1,03 & 0,57 & 2010 & 28579 & 7,03 & 14,61 & 8,04 \\
\hline Uruguay & 0,02 & 0,01 & 41 & 49616 & 0,08 & 25,73 & 11,38 \\
\hline Uzbekistan & 0,23 & 0,14 & 638 & 63525 & 1,00 & 23,03 & 13,67 \\
\hline Zambia & 0,67 & & 1040 & 27957 & 3,71 & 18,18 & \\
\hline Zimbabwe & 0,88 & 0,49 & 726 & 17986 & 4,04 & 21,72 & 12,26 \\
\hline
\end{tabular}

Sources : Gouvernment Revenue Dataset (UNU-WIDER), Official Development Dataset (OECD).

Note: Empty cells correspond to missing data rergading indirect tax revenue. 
Exempting aid leads to distortions in favour of imports at the expense of locally provided goods and services. Non-taxation of aid mechanically modifies the structure of incentives and gives rise to distortions. As products imported under such aid are not subject to the same tax regime as comparable products in the national market outside the scope of the aid, it is less attractive to buy locally. ${ }^{20}$ This import-favouring bias of aid is not new. For instance, the aim of the Bellmon amendment to the Public Law 480 was to protect the production of local farmers (see Deaton, 1980). Moreover, as mentioned in the previous point, some firms may try to take advantage of the exemptions granted to foreign aid activities for other ends, giving rise to unfair competition with other local or foreign firms.

Non-taxation of project aid encourages tax fraud and corruption by offering a path for circumventing the rules. Like any exemption, it breaks the tax chain - especially for VAT complicating the task of tax auditing. Maintaining the system of exemptions amounts to encouraging the growth of the informal sector. For tax and customs authorities in recipient countries, managing, monitoring, and auditing exemptions for project aid against the backdrop of a significant risk of fraud constitute a considerable additional workload (Orlowski, 2007). In addition to the loss of revenue, tax exemptions for aid hamper already-limited human and financial capacities (International Tax Dialogue, 2005, 2006). For instance, it is difficult to trace exempted goods. Authorities must ensure that these goods are indeed intended for the projects for which they have been allocated and not sold in the domestic market in competition with firms subject to the ordinary tax code. In developing countries, moreover, the categorisation and codification of customs exemptions are not conducive to rigorous monitoring or to estimations of their budgetary impact.

Tax exemptions of aid led some recipient countries to record revenue losses as their own contributions to the project. For instance, the Togolese Government adopted Order No. $93 / 005,{ }^{21}$ which defined the tax regime of project aid. Similarly, Guinea establishes the Instruction $N^{\circ} 196 / 414 / \mathrm{PM} / \mathrm{MBRSP}$. In these legal texts the State commits to bear the financial part of the tax burden (direct and indirect taxes and duties) of the operation. After a series of administrative procedures, the contractor receives Treasury cheques, which allow it to pay relevant taxes and tariffs. Treasury cheques induce fictitious collected tax revenues as

\footnotetext{
${ }^{20}$ For example, a local supplier will not be able to collect VAT and therefore to deduce VAT from its inputs. Instead, it will be forced to carry over some of this VAT in the price of its service or reduce its profit margin. Exemptions for the suppliers of the donor's supplier could also be considered. This solution, which has been adopted in the agricultural, mining, and oil sectors, is particularly costly in terms of tax revenue and does not favor the formalization of the economy.

${ }^{21}$ See the Instruction $N^{\circ} 196 / 414 / P M / M B R S P$ portant mesures d'application du régime fiscal des marches publics et projets publics du 13/12/1996.
} 
"balancing transactions" equal to the granted exemptions. Such behaviour may have a macroeconomic impact on the ratio of tax revenue to GDP and leads to significant and damaging overestimates of countries' capacity to mobilise domestic tax revenue.

Finally, tax aid exemptions may affect the effectiveness of donors' assistance policy and their respective credibility. First, exemptions for project aid involve significant transaction costs for donor countries. Understanding texts and procedures can be a sizeable administrative burden, especially in the presence of a large number of bilateral agreements. Procedures for granting exemptions are generally time-consuming, requiring many cumbersome and repetitive processes that involve different departments and delay clearance times. The mechanisms introduced by recipient countries in recent years to better monitor and control exemptions (treasury cheques, lists, quotas) make these procedures even more cumbersome.

Second, exempting aid erodes donors' credibility and consistency between statements and actions. All donors and financial partners - with the IMF at the fore - encourage the fight against the proliferation of exemptions. Recognised as a barrier to domestic resource mobilisation, their economic efficiency in attracting FDI or reducing inequality is also controversial. In the interests of consistency and exemplarity, these same donors can hardly seek special tax arrangements for their foreign aid activities. There are no obvious reasons why tax arrangements regarding aid-funded goods and services should not be debated like the rest of tax expenditure. It seems problematic for donors to both make domestic resource mobilisation in developing countries a high priority and continue to benefit from tax exemptions on their project aid.

Moreover, the maintenance of tax aid exemption runs counter to donors' discourse on strengthening the capacities of tax authorities and the commitments made in the Paris Declaration on Aid Effectiveness (2005) and the Monterrey Consensus (2002) on Financing for Development. Indeed, donor countries have committed to "reduce transaction costs" and to “increase alignment of aid with partner countries' priorities, systems, and procedures and help to strengthen their capacities" (United Nations, 2002). Keeping the taxation of ODA outside the scope of ordinary law runs counter to these commitments. It increases the workload of tax and customs administrations and diverts their resources from tax collection objectives. 


\section{The policy initiative}

The practice of exempting ODA-financed projects from tax is as old as foreign aid itself(19501960). Wary of the quality of recipient countries' financial and other institutions, donors preferred to circumvent national systems by setting up their own agencies or institutions. ${ }^{22}$ Tax and customs exemptions for these aid programs naturally followed. Donors justified their demands for exemptions by citing the "unreasonable" nature of the tax systems of most developing countries (ITD, 2006) with regard to both tax policy and administration: high rates, myriad taxes or rates, tax law lacking transparency, abusive interpretation of legislation, and risk of discrimination and corruption. In particular, before the reforms undertaken as part of structural adjustment programs, customs tariffs were characterised by a large number of taxes and different rates for similar products. ${ }^{23}$ Moreover, the use of non-tariff instruments was widespread.

Some donors remain opposed to the taxation of aid, thus contributing to the status quo. There are at least four explanations: (1) Taxing aid reduces the amount of aid allocated directly to projects (in the order of 10 percent to 20 percent of the total amount allocated); (2) It runs the risk that collected taxes and duties might be poorly used or even have a negative long-term impact on governance. This second argument is particularly relevant in the case where recipient countries display such low governance indicators that they are not eligible to budget support (e.g. Liberia, Somalia, and Zimbabwe); (3) Project aid also gives greater visibility to donors' actions than general budget support; (4) There is also consideration of the risk of unequal treatment between the $30 \mathrm{DAC}$ donors and non-member countries - China, in particular-, if the former opt for the taxation of aid.

In addition, donors preferred - and continue to prefer - project aid, which is more visible and comes with targets, over general budget support because of common perceptions of inefficient public spending management. Figure 1 displays the evolution of the composition of foreign aid over the period 2007-2015 and stresses the preponderance of project aid over other types of aid. In cases of recipient countries considered to be poorly governed or corrupt, donor countries would seek to avoid directly feeding their budgets. Last, as ODA replaces actions the failed state should have financed by mobilising its own resources, donors have had difficulty justifying paying taxes or duties on these activities. On the contrary, exemptions came to be seen either implicitly or explicitly as recipient countries' contribution to project financing.

\footnotetext{
${ }^{22}$ Knack (2013) studied decisions to bypass recipient country institutions. The author highlighted the role of donors' trust in these institutions, their quality, and risk aversion on the part of donor countries.

23 These rates could vary very significantly depending on whether or not the good could be produced locally.
} 
Further, recipient countries had not previously demonstrated any concerted initiative to tax foreign aid. Competition among them to attract donors is a potential explanation. Another is the ability of political leaders in some recipient countries to divert more easily foreign aid than taxation. While tax participates to modern state building (Brautigam et al., 2008), Djankov et al. (2008) show empirically that foreign aid damages democratic rules in recipient countries and that this aid curse is larger than resource (oil) curse. ${ }^{24}$

If donor countries initially justified exemptions by citing the inefficiency of recipient countries' tax systems and administrations, this argument has now lost its potency following the numerous reforms that have been implemented to improve tax systems (such as rate cuts and simplification) and to modernise tax departments in most recipient countries.

Some donor countries have programs in place to provide tax-exempt project aid and budget support for the same country. This may result from the multiplicity of institutions, agencies, and ministries involved in donor countries' ODA policy, but it does underline some inconsistency in ODA at the level of the recipient country. Since the discussion began on the taxation of aid, the DAC has ensured that if project aid were to be taxed, it would be accounted for as tax-inclusive. Taxation of ODA-financed projects would then have no impact on the total amount of aid allocated by donors. The loss of resources for each project due to taxation would be offset by the payment of the tax, amounting to general budget support. Thus, the amount of aid allocated to projects would be reduced by the amount of tax paid, but the volume of total aid would remain unchanged since the recipient country would receive the income from these taxes. If donor countries wished to continue to provide project aid and budget support, they would simply have to offset the automatic allocation of a portion of project aid to budget support by rebalancing the two instruments so that the share of project aid is increased in the total volume of aid. However, when the country in question does not provide budget support, the issue remains unsolved. This is the case for most DAC member countries, where budget support represented less than 1 percent of total ODA in 2015 compared with 3.23 percent in 2007 (see Figure 1). For the majority of countries that do provide it, it has largely been on a downward trend. Nevertheless, some countries, such as Portugal, which opposes the taxation of aid precisely because it would result in a reduction in available funds for project aid, provide significant levels of budget support: 12.81 percent for Portugal compared with 9.57 percent for New Zealand, 8.5 percent for Russia, and 7.54 percent for Ireland on average between 2000 and 2015 (see Figure 3). As Netherlands and Norway that have decided to stop asking for some

\footnotetext{
${ }^{24}$ These authors test empirically the effect of aid on democracy in 108 recipient countries over the period 1960 to 1999.
} 
ODA tax exemptions (Steel et al., 2018), Ireland is already beginning to forgo tax exemptions on project aid. Great Britain, which does not have an official position, allocated on average 5.3 percent of its aid to budget support between 2000 and 2015.

The purpose of taxing project aid contributes to broaden the tax base by rationalising some tax expenditure. This would lead to an improvement in recipient countries' tax revenue to GDP ratio, easing tax on the "modern formal" sector and even help with the formalisation of developing economies, as tax authorities would then have better knowledge of the turnover of donors' local suppliers, mainly via the simple calculation of Value Added Tax (VAT) deductibility.

An increase in general budget support would offer vital fiscal leeway to recipient countries to pursue their own development policies in accordance with the principle of appropriation. As donors become taxpayers, it would also strengthen political dialogue in recipient countries over their tax policies within a framework of mutual responsibility and appropriation.

The 2005 Paris Declaration on Aid Effectiveness called on donors to use or strengthen existing national systems with a view to improving recipient countries' appropriation of aid. Despite their commitments, donors' use of recipient countries' Public Finance Management (PFM) systems is still far from systematic (see Figure 2). Although not mentioned explicitly in the Paris declaration, tax and customs systems are an important part of PFM systems. Since 2005, the World Bank officially announced first its willingness to pay taxes if the recipient country's taxes are "reasonable." ${ }^{25}$ Following this approach, other donors decided to review their position within the framework of the International Tax Dialogue (ITD). ${ }^{26}$

ITD published several documents, including draft guidelines for the tax treatment of aid-funded projects prepared by the secretariats of the member organisations (ITD, 2006, 2007). These guidelines were supposed to give rise to a recommendation by the United Nations Economic and Social Council (ECOSOC). However, the draft guidelines were never finalized, and no other document resulting from a global and organised approach to taxing project aid has been made public since 2007. The issue of exemptions for aid-funded projects continues to be raised frequently in discussions on aid funding (for example, at the OECD's annual meeting in Kampala in 2009), without this leading to concrete initiatives (OECD, 2009). ${ }^{27}$

\footnotetext{
25 "To eliminate these inconsistencies and distortions and reduce transaction costs in the administration of Bank-financed projects, Bank policy would be changed to provide Bank financing for the reasonable costs of taxes and duties associated with project expenditures." (World Bank, 2004, p. 11). The authors are not aware of any effective implementation of such a commitment. ${ }^{26}$ The ITD is a joint initiative of the European Union Commission, the Inter-American Development Bank, the IMF, the OECD, the World Bank, and the Inter-American Center of Tax Administrations.

${ }^{27}$ In 2010, France considered establishing a working task force to study this issue. This working group would have measured the impact of aid taxation and discussed the issue with the various stakeholders before presenting a proposal to the DAC to set in motion a fresh round of discussion.
} 
Today, the major donors say they are ready to forgo aid exemptions, many of them expressing a desire for this to take place as part of a joint initiative, in particular under the aegis of the European Union. Officially, they accept the idea of tax-inclusive project finance, sometimes with some conditions, notably the application of "reasonable" or "efficient" taxation. Broadly speaking, the countries that have honoured the Paris Declaration's commitments by using national PFM systems are generally those that favour the taxation of project aid (see Figure 2). ${ }^{28}$ However, despite this change of discourse, the commitments made and a relative consensus on the benefits of a move towards taxing project aid, the status quo remains and foreign aid-funded projects still enjoy taxes and duties exemption. ${ }^{29}$

\section{Conclusion}

The aim of this note is to participate to the current debate on the taxation of aid. Since the Addis Ababa conference in August 2015, domestic revenue mobilisation is the main tool for developing countries to finance their development and foreign aid is a secondary source of funding. Several developing countries engaged in streamlining their tax system by reducing several tax rates and broadening relative tax base. One privileged tool has been the assessment and the publication of tax expenditures. Tax exemption of ODA affects this effort. Revenue losses are not negligible particularly in fragile States (1 to 3 percent of GDP). Moreover, it induces several distortion costs such as favouring importations over local purchases, increasing the complexity of recipient countries tax systems and the risk of fraud.

Today, donors are more open to the taxation of project aid. Discussion has led to the recognition of changes in the international aid environment, resulting in a (theoretical) warming to the taxation of aid. It has also led to a recommendation for dialogue between donors and recipient countries to tax foreign aid-funded projects. Nevertheless, in practice, little change has taken place. No international guidelines on the taxation of aid projects have been issued, and no organised discussions between donors and recipient countries have been initiated. The coordination of tax policies within the framework of regional integration should nevertheless encourage both donors and recipients to revive dialogue at the regional level. The notion of

\footnotetext{
28 There are a few exceptions: Romania is opposed but uses national procedures for 90\% of its aid; Belgium and Luxembourg are in favor but have done little to meet the commitments of the Paris Declaration. The use of national systems is a signal of confidence among donors in the systems of recipient countries, which may explain donors' stance on the taxation of project aid.

${ }^{29}$ Some countries are beginning to forgo exemptions. France has embarked on this process through "debt reduction and development contracts" (C2D), which finance tax-inclusive development projects and programs.
} 
"reasonable taxation" frequently associated with a favourable position on the part of donors remains unspecified if such a notion is definable.

The taxation of foreign aid would improve the consistency of donors regarding their respective aid policy. Donors emphasize that domestic revenue should be the main financing source of development, but they continue in claiming tax exemptions for their projects. Consequent tax expenditures narrow the tax bases of recipient countries and their efforts in mobilizing more revenue. Agreeing on the taxation of their aid would be also a sign of respect from the donors towards the institutions of the recipient countries (in particular, their tax systems) in line with the 2005 Paris Declaration on Aid Effectiveness.

Numerous questions remain unresolved and deserve more in-depth discussion and study, including (but not limited to): What impact would the taxation of project aid by donors have on tax revenue in beneficiary countries? What is the administrative cost (in time and resources) of keeping such a system in place for both donors and recipient countries? Beyond the direct (revenue) and indirect (administrative cost) financial impact of tax exemptions, what policy implications do they entail for both donors and recipients? What initiatives can beneficiary countries undertake to curb the exemptions they grant? How can the reluctance to pay tax be lifted? What would the cost of change be for donor administrations, and does this explain the status quo? 
Figure 1 : ODA by sector, DAC data

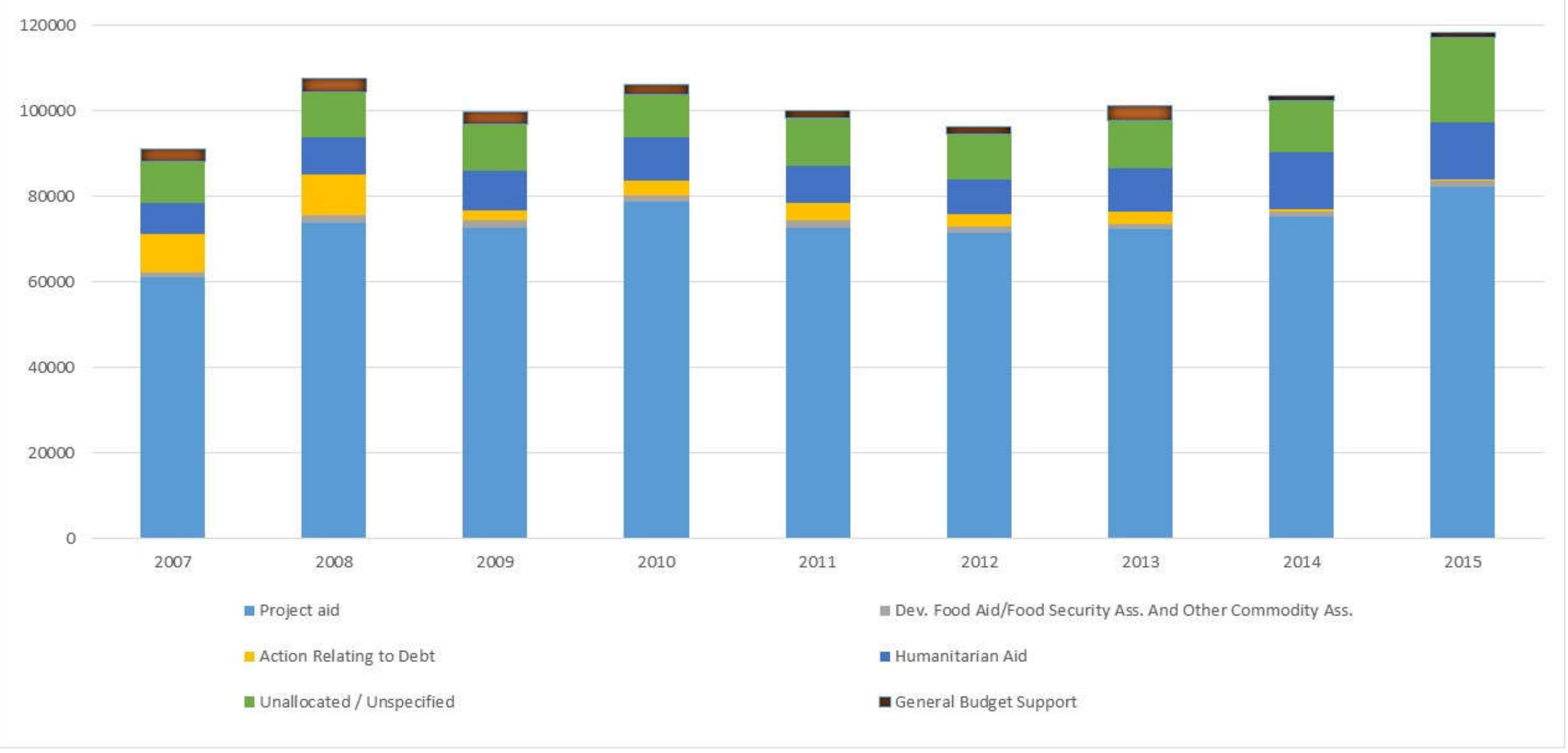




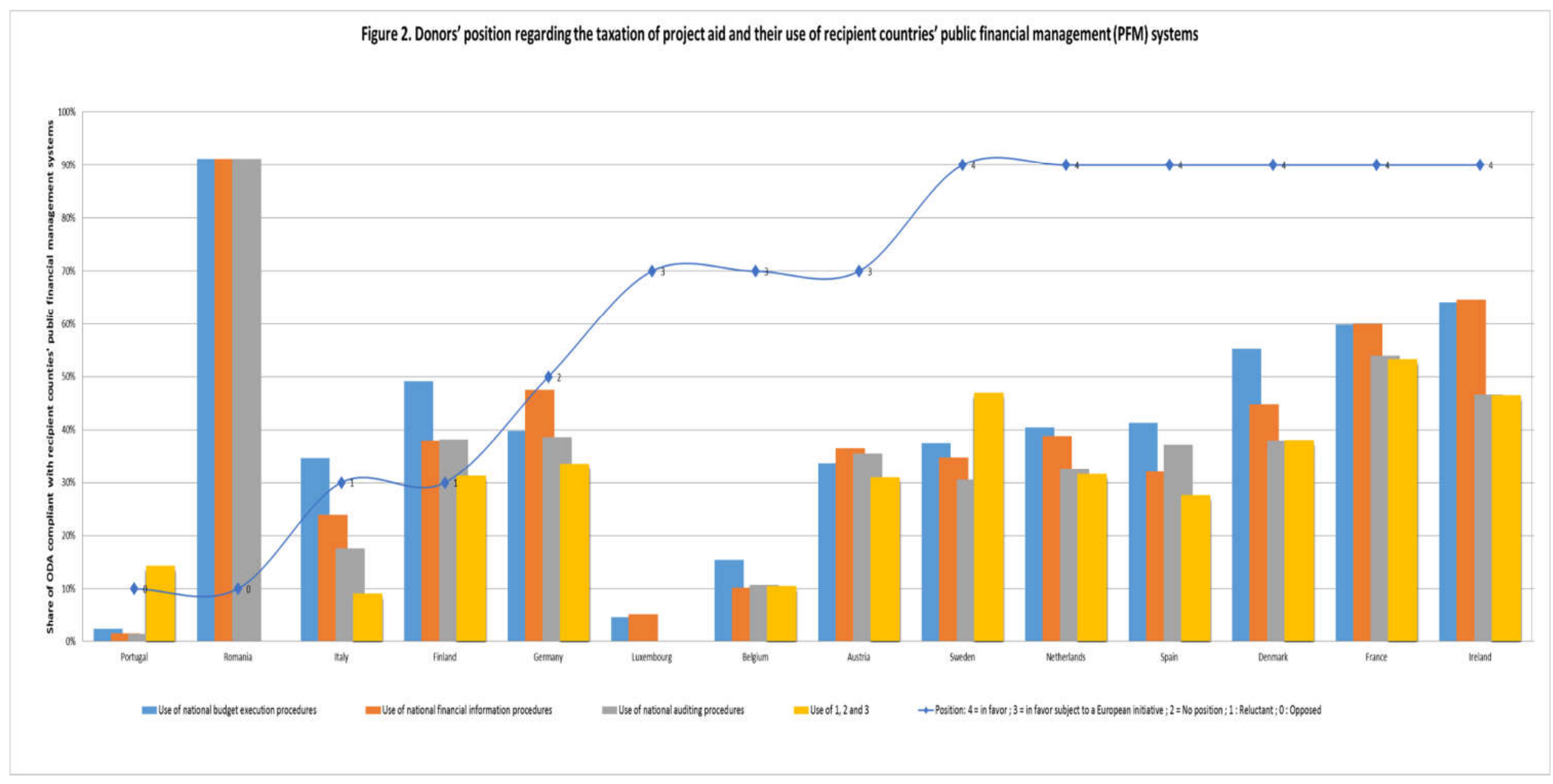




\section{Figure 3: Share of different types of ODA by country (2000-2015)}

- Soutien budgétaire $\quad$ Aide projet $\quad$ Aide humanitaire $\quad$ Action se rapportant à la dette Non spécifié

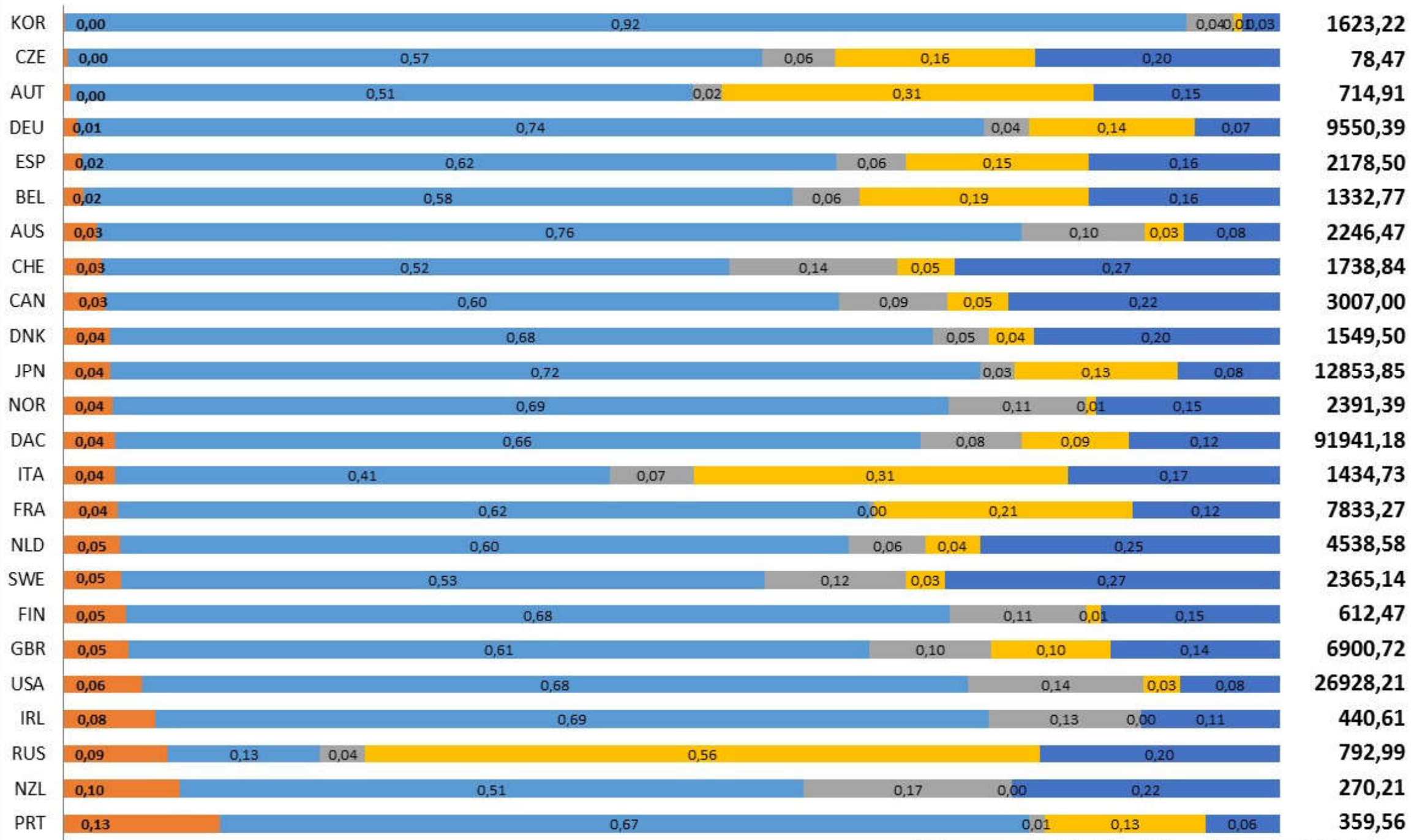

Total amount of aid, in Million of constant US dollars, 2015 


\section{References}

Benedek, D., Crivelli, E., Gupta, S. and P. Muthoora, 2012. Foreign Aid and Revenue: Still a Crowding Out Effect?, IMF Working Papers WP/12/186, International Monetary Fund.

Bräutigam, D., Feldstadt, O.-H. and M. Moore, 2008. Taxation and State-Building in Developing Countries: Capacity and Consent Cambridge: Cambridge University Press.

Buchanan, J. M., 1975. “The Samaritan's dilemma," in E.S. Phelps (ed.): Altruism, morality and economic theory, New York: Russel Sage foundation, pp. 71-85.

Burnside, C. and D. Dollar, 2000. "Aid, Policies, and Growth," American Economic Review, 90(4), pp. 847-68.

Carter, P., 2013. “Does Foreign Aid Displace Domestic Taxation?”, Journal of Globalization and Development 4(1), pp. 1-47.

Clemens, M. A., Radelet, S., Bhavnani, R and S. Bazzi, 2012, "Counting chickens when they hatch: timing and the effects of aid on growth," Economic Journal, 122, pp. 590-617.

Clist, P. and Morrissey, O., 2011. "Aid and tax revenue: Signs of a positive effect since the 1980s," Journal of International Development 23(2): 165-180.

Deaton, B. J., 1980. "Public Law 480: The Critical Choices," American Journal of Agricultural Economics, 62 (5), pp. 988-992.

Déclaration de Paris sur l'efficacité de l'aide au développement, 2005, Paris.

Diallo, S., 2013. "Tax exemptions for aid-funded projects: reasons for change”, International Center for Tax and Development, 14 March, 2013.

Djankov, S., Montalvo, J.G. and M. Reynal-Querol, 2008, "The curse of aid." Journal of Economic Growth, 13(3), pp. 169-194.

Gupta, S., Clements, B., Pivovarsky, A., and Tiongson, E., 2004. "Foreign Aid and Revenue Response: Does the Composition of Aid Matter?," in S. Gupta, B. Clements and G. Inchauste (eds), Helping Countries Develop: The Role of Fiscal Policy, Washington: International Monetary Fund.

International Monetary Fund (IMF), 2011. Revenue Mobilization in Developing Countries, Fiscal Affairs Department, International Monetary Fund. 
International Tax Dialogue (ITD), 2005. First Global International Tax Dialogue (ITD) Conference, Rome, March.

International Tax Dialogue (ITD), 2006. Tax treatment of donor-financed projects.

Keen, M. Mansour, M., 2010. "Revenue mobilisation in sub-Saharan Africa: challenges from globalisation", Development Policy Review, 28 (5).

Knack, S., 2013, “Aid and donor trust in recipient country systems," Journal of Development Economics, 101, pp. 316-329.

Mansour, M. and G. Rota-Graziosi, 2014, "Tax coordination and Competition in the West African Economic and Monetary Union," Tax Note International, Special Reports, April.

Op de Beke, A., 2014. Réforme des administrations fiscales dans les pays francophones en Afrique subsaharienne, International Monetary Fund.

Organisation de coopération et de développement économiques (OCDE), 2009. Issues note on the tax treatment of aid funded goods and services, Task team on taxation and governance, The Serena Hotel, Kampala, 18 November 2009.

Orlowski, D., 2007. “Donors' Principles and Resulting Stress: Indirect Taxes and Donorfunded Public Works," Fiscal policy and tax incidence, Ministry of Planning and Development of Mozambique.

Prichard, W., Brun, J-F. and O. Morrissey, 2012. "Donors, Aid and Taxation in Developing Countries: An Overview," ICTD Working Paper 6, International Centre for Tax and Development.

Schultz, T. W., 1960. "Value of U.S. Farm Surpluses to Underdeveloped Countries." Journal of Farm Economics, 42 (5), pp. 1019-30.

Steel, I., Dom, R., Long, C., Monkam, N. and P. Carter, 2018, The taxation offoreign aid. Don't ask, don't tell, don't know, ODI, Brief Paper. 